Synthesis, part of a Special Feature on Do we need new management paradigms to achieve sustainability in tropical forests?

\title{
Accounting for the Ecological Dimension in Participatory Research and Development: Lessons Learned from Indonesia and Madagascar
}

\author{
$\underline{\text { Yves Laumonier }}^{1}, \underline{\text { Robin Bourgeois }}^{1}$, and $\underline{\text { Jean-Laurent Pfund }}^{2}$
}

\begin{abstract}
The lack of understanding on how to integrate ecological issues into so-called socialecological natural resource management hampers sustainability in tropical forest landscape management. We build upon a comparison of three cases that show inverse gradients of knowledge and perceptions of the environment and human pressure on natural resources. We discuss why the ecological dimension currently lags behind in the management of tropical forest landscapes and to what extent participatory development can enhance the fit among ecological, socio-cultural, and economic systems. For each case study, socio-cultural and anthropological aspects of society and indigenous knowledge of the environment, the distribution of natural resources, classification, and management are documented in parallel with biophysical studies. Our results confirm that the ecological dimension remains weakly addressed and difficult to integrate into development actions when dealing with tropical forested landscape management in developing countries. We discuss three issues to understand why this is so: the disdain for traditional ecological knowledge and practices, the antagonism between economy and ecology, and the mismatch between traditional and modern governance systems. Participatory development shows potential to enhance the fit among ecological, socio-cultural, and economic systems through two dimensions: the generation and sharing of information to understand trends and the generation of new coordination practices that allow stakeholders to voice environmental concerns. In the absence of a "champion," institutions, and financial resources, the expected outcomes remain on paper, even when changes are negotiated. Future research in natural resource management must emphasize better integration at the interface of ecology and governance. Finally, we identify three challenges: the design of operational tools to reconcile ecology with social and economic concerns, the creation of governance systems to institutionalize collaborative and integrated resource management, and the design of enabler organizations close to local communities.
\end{abstract}

Key Words: ecological dimension; Indonesia; Madagascar; management of natural resources; multiple stakeholders; participatory research and development; tropical forest landscapes

\section{INTRODUCTION}

At the interface of environmental and social issues, not enough is known about the links between policies, regionally important biophysical factors, local natural resource management sustainability, and livelihoods. There is still a need for better understanding of environment-development relationships that are particularly relevant to policy-making and livelihoods and that will enable the development and validation of improved natural resource management, conservation, and development strategies in tropical forested landscapes. Reconciling ecology and the pressure of economic forces into appropriate policy and management strategies in such areas requires the facilitation of a participatory development approach for the empowerment of local stakeholders in land use and resource management planning (Frost et al. 2006) and a deeper analysis of social-ecological systems at a landscape level (van Noordwijk et al. 2001, Zuidema and Sayer 2003). Community views and perceptions of conservation and landscape need to be understood and documented in a format that is readily accessible to planners and developers (Sheil et al. 2006, Vermeulen and Sheil 2007).

The participation of local communities and other 
stakeholders in such planning and management processes has long been advocated as a mandatory step to achieve sustainability in development (Brinkerhoff and Garcia-Zamor 1986, Marsden and Oakley 1990, Cernea 1991). The demand from development and conservation agencies and international nongovernmental organizations for more participatory development keeps growing (World Bank 1996, Brinkerhoff 1997, Gonsalves et al. 2005) while research emphasizes the development of new adaptive co-management concepts (Folke et al. 2002, Olsson et al. 2004, Colfer 2005). Campbell and Vainio-Mattila (2003) have discussed the many complexities involved in the application of this participatory development concept (also referred to as participatory resource management or community-based natural resource management), as opposed to the community-based conservation (biodiversity conservation) concept. Here, we use the following definition of participatory development: "a process through which stakeholders can influence and share control over development initiatives, and over the decisions and resources that affect them. Stakeholders are those affected positively or negatively by the outcome, or those who can affect the outcome of a development activity or program" (Asian Development Bank 1996).

The interdependent ecological, economic, and socio-cultural dimensions of sustainable development and the fit of these dimensions have been abundantly researched and documented since the 1992 United Nations conference in Rio de Janeiro, Brazil, and the development of the social-ecological system concept of Berkes and Folke (1998). However, 10 yr after their initial essay on the problems of fit between ecosystems and institutions, Folke et al. (2007) point out that the "dominant work on economic and social globalization still lacks the connection to the biosphere and ecosystem capacity." We subscribe to this statement because, notwithstanding a significant amount of ecological research, progress in integrating the ecological dimension into the development of tropical landscapes remains quite slow. Although ecological guidelines for land management decisions are regularly recommended in the landscape ecology approach (Forman and Godron 1986, Forman 1995, Dale and Haeuber 2001), they remain mostly on paper. The lack of understanding of how to integrate ecosystem information into natural resource management also limits the potential to minimize trade-offs between conservation and development
(Sayer and Campbell 2004). Ecological science does not have much policy impact in Western countries (Stevens et al. 2007), and the situation is even worse in developing countries where purely economic growth criteria still largely dominate development paradigms.

Why then is the ecological dimension always lagging behind in tropical forest landscape management, and to what extent can participatory development enhance a better fit between ecological, socio-cultural, and economic systems? To discuss this, we use a comparative approach based on three case studies selected from our experience in Indonesia and Madagascar. For these cases, we analyzed key social-ecological features and sought multistakeholder consensus on sustainable development through participatory knowledge generation.

\section{SITES AND METHODS}

\section{Site selection}

We selected three cases that represent a gradient of population pressure on the environment, which pressure nevertheless is uncorrelated with the size of the population; in fact, the smallest population density had the most degraded environment: Tanimbar, Indonesia; Beforona, Madagascar; and Mahakam Delta, Indonesian Borneo. These cases illustrate three rural development schemes of tropical landscapes that are characterized by the occupation and influence of a traditional society, traditional society mixed with migrants, and migrants only, respectively. We used specific criteria to substantiate the comparability of these cases (Table 1). There was high consistency among the cases, justifying their relevance for a comparative analysis. Although the comparative exercise creates challenges in drawing generic meaning across the three cases, it illustrates the diversity of realities related to the ecological dimension of participatory development and lays the foundation for a discussion of common lessons learned. We characterized the main features of the three forested regions in which the management of natural resources is being approached through participatory development (Table 2).

The Tanimbar Archipelago, located in the Moluccas, eastern Indonesia, is dominated by the island of Yamdena. It shares the problems of many 
Table 1. Background information for the inductive comparison and comparability of the cases.

\begin{tabular}{|c|c|c|c|}
\hline Criterion & Tanimbar (Indonesia) & Beforona (Madagascar) & Mahakam Delta (Indonesia) \\
\hline $\begin{array}{l}\text { Intensity of } \\
\text { pressure on the } \\
\text { environment }\end{array}$ & $\begin{array}{l}\text { Low pressure by long-established } \\
\text { local communities }\end{array}$ & $\begin{array}{l}\text { Medium to strong pressure by } \\
\text { local communities and a few } \\
\text { recent migrants }\end{array}$ & $\begin{array}{l}\text { Strong pressure by very recent } \\
\text { local communities of migrants }\end{array}$ \\
\hline Stakeholders & $\begin{array}{l}\text { Multiple: local population, local } \\
\text { government, local technical } \\
\text { agencies, local traders, } \\
\text { nongovernmental organizations, } \\
\text { regional and national government, } \\
\text { private companies }\end{array}$ & $\begin{array}{l}\text { Multiple: local population, local } \\
\text { government, local traders, } \\
\text { nongovernmental organizations, } \\
\text { regional and national technical } \\
\text { agencies, regional and national } \\
\text { government }\end{array}$ & $\begin{array}{l}\text { Multiple: local population, local } \\
\text { government, nongovernmental } \\
\text { organizations, private } \\
\text { companies, international } \\
\text { companies }\end{array}$ \\
\hline $\begin{array}{l}\text { Knowledge gener- } \\
\text { ation }\end{array}$ & $\begin{array}{l}\text { Multidisciplinary, multiple tools, } \\
\text { multiscale, integrated results }\end{array}$ & $\begin{array}{l}\text { Multidisciplinary, multiple } \\
\text { tools, multiscale, integrated } \\
\text { results }\end{array}$ & $\begin{array}{l}\text { Multidisciplinary, multiple } \\
\text { tools, multiscale, integrated } \\
\text { results }\end{array}$ \\
\hline $\begin{array}{l}\text { Stakeholder invol- } \\
\text { vement }\end{array}$ & $\begin{array}{l}\text { Participation in the design and } \\
\text { implementation of research, } \\
\text { discussion, and validation of the } \\
\text { results }\end{array}$ & $\begin{array}{l}\text { Participation in the design and } \\
\text { implementation of research, } \\
\text { discussion, and validation of the } \\
\text { results }\end{array}$ & $\begin{array}{l}\text { Participation in the design and } \\
\text { implementation of research, } \\
\text { discussion, and validation of the } \\
\text { results }\end{array}$ \\
\hline
\end{tabular}

small islands in that it is geographically, politically, and economically isolated; most livelihoods are heavily dependent on subsistence agriculture and wild products from the sea and forest. Standard poverty indicators are worse than for Indonesia as a whole. The people are confined to the coast and depend on inland forested catchments for fresh water during the dry season. The forest still covers $70 \%$ of the land, an exceptional situation in Indonesia. In this fragile environment, livelihoods could very easily be threatened by unsustainable exploitation of resources and poorly planned development.

The Beforona region, located approximately 160 $\mathrm{km}$ east of Antananarivo, is located on the eastern escarpment of Madagascar, for which the deforestation history is well documented (Faramalala 1995, Brand 1998). The littoral zone was already partly deforested at the beginning of the 19th century, mostly for rice cultivation and zebu ranching. Higher on the escarpment, new villages were developed from the middle to the end of the 19th century, often in relation to logging activities (Zurbuchen 2004). The eastern coast of Madagascar had lost approximately one-third of its original forest cover by 1950 and two-thirds by 1985 (Green and Sussman 1990). The study site covers a gradient of vegetation degradation from the remaining forests at an elevation of approximately $1200 \mathrm{~m}$ above sea level to lowland areas close to the littoral zone.

The Mahakam Delta is located on the east coast of Kalimantan, Indonesian Borneo. The original vegetation consisted of swamp formations with a vegetation succession from upstream to seashore of freshwater swamp forest, pure Nypa fructicans stands, and mixed Nypa and mangrove vegetation. The dominant Nypa used to cover 55\% of the total vegetation area, representing one of the biggest unmixed formations of this type in the world. Until the 1970s, access to the Mahakam Delta remained difficult and the environment was inhospitable. Human activities were sparse and mainly located in a few coastal villages. The local population consisted of descendants of the Bugis and Bajo migrants from nearby Sulawesi, who brought their own fishing folk culture with them. 
Table 2. Main features of the three forested regions in which the management of natural resources is being approached through participatory research and development.

\begin{tabular}{|c|c|c|c|}
\hline Feature & $\begin{array}{l}\text { Tanimbar archipelago } \\
\text { (Indonesia) }\end{array}$ & $\begin{array}{l}\text { Beforona region } \\
\text { (Madagascar) }\end{array}$ & Mahakam Delta (Indonesia) \\
\hline Location & $7^{\circ} 35^{\prime} \mathrm{S}, 131^{\circ} 36^{\prime} \mathrm{E}$ & $18^{\circ} 58^{\prime} \mathrm{S}, 48^{\circ} 34^{\prime} \mathrm{E}$ & $0^{\circ} 45^{\prime} \mathrm{S}, 117^{\circ} 28^{\prime} \mathrm{E}$ \\
\hline Area & $\begin{array}{l}3300 \mathrm{~km}^{2} \text { (Yamdena Island) } \\
\text { of which } \sim 970 \mathrm{~km}^{2} \text { is } \\
\text { agricultural landscape }\end{array}$ & $\begin{array}{l}\text { A corridor of } 250 \mathrm{~km}^{2}(30 \\
\mathrm{km}^{2} \text { for selected village } \\
\text { territories })\end{array}$ & $1500 \mathrm{~km}^{2}$ \\
\hline Physiography & $\begin{array}{l}0-250 \mathrm{~m} \text { in elevation; rolling } \\
\text { hills, dissected topography }\end{array}$ & $\begin{array}{l}200-1200 \text { m in elevation; } \\
\text { hilly and steep slopes, } \\
\text { dissected topography }\end{array}$ & $\begin{array}{l}0-5 \mathrm{~m} \text { in elevation; swampy } \\
\text { lowlands }\end{array}$ \\
\hline Rainfall & $1500-2500 \mathrm{~mm} / \mathrm{yr}$ & $2000-3500 \mathrm{~mm} / \mathrm{yr}$ & $2000-2500 \mathrm{~mm} / \mathrm{yr}$ \\
\hline Population & $\begin{array}{l}\text { 51,000 (Yamdena Island); } \\
\text { selected villages: } 500 \text { to } 2500 \\
\text { inhabitants }\end{array}$ & $\begin{array}{l}20,000 \text { (two communes); } \\
\text { selected villages: } 150 \text { to } 350 \\
\text { inhabitants }\end{array}$ & $\begin{array}{l}20,000 ; \\
\text { selected villages: } 1000 \text { to } \\
2000 \text { inhabitants }\end{array}$ \\
\hline Population density & $\begin{array}{l}\text { Island density: } 15 \text { people/ } \\
\mathrm{km}^{2} \text {, rural density: } 52 \text { people/ } \\
\mathrm{km}^{2}\end{array}$ & $\begin{array}{l}\text { Commune density: } 80 \\
\text { people } / \mathrm{km}^{2}, \text { rural density: } 30 \\
\text { people } / \mathrm{km}^{2}\end{array}$ & 13 people $/ \mathrm{km}^{2}$ \\
\hline Annual population growth & $<2 \%$ & $3 \%$ & $4 \%$ \\
\hline Settlement & $\begin{array}{l}\text { Scattered settlements and one } \\
\text { small town (Saumlaki: } \\
15,000 \text { inhabitants) }\end{array}$ & $\begin{array}{l}\text { Scattered settlements and } \\
\text { two small towns (one town is } \\
\text { Beforona: } 10,000 \\
\text { inhabitants) }\end{array}$ & Scattered settlements \\
\hline Land cover & $\begin{array}{l}\text { Lowland rainforest, moist } \\
\text { deciduous and dry decidous } \\
\text { forests, secondary growth, } \\
\text { food crop fields }\end{array}$ & $\begin{array}{l}\text { Altitudinal sequence from } \\
\text { grassland region of the east } \\
\text { coast to hill forest remnants } \\
\text { up to } 800 \mathrm{~m} \text { above sea level } \\
\text { with submontane forest } \\
\text { above, secondary growth, } \\
\text { food crop fields, home } \\
\text { gardens }\end{array}$ & $\begin{array}{l}\text { Fish ponds, some degraded } \\
\text { mangrove swamp and Nypa } \\
\text { vegetation }\end{array}$ \\
\hline $\begin{array}{l}\text { Social-ecological concerns } \\
\text { and development needs }\end{array}$ & $\begin{array}{l}\text { Still relatively little pressure } \\
\text { on environment from local } \\
\text { society / Customary rules } \\
\text { still in use / Growing } \\
\text { pressure from outsiders and } \\
\text { local government to exploit } \\
\text { intact natural resources } \\
\text { (forest and sea) / Danger of } \\
\text { anarchic development for a } \\
\text { very fragile environment }\end{array}$ & $\begin{array}{l}\text { Long-lasting ecological } \\
\text { decline related to slash-and- } \\
\text { burn practices for upland rice } \\
\text { cultivation / Last forest } \\
\text { pioneer front at the top of the } \\
\text { escarpment / High pressure } \\
\text { on natural resources due to } \\
\text { demography and migration / } \\
\text { Effects of migrants on the } \\
\text { farming system }\end{array}$ & $\begin{array}{l}\text { Complete deforestation and } \\
\text { environmental degradation for } \\
\text { shrimp aquaculture / Extreme } \\
\text { pressure on natural resources } \\
\text { exploited by migrants / No } \\
\text { customary rules }\end{array}$ \\
\hline
\end{tabular}




\section{Methods}

The methodology was the same at each site. The main stakeholders were identified first. The socialecological and economic data were then acquired, and stakeholder involvement was fostered for consensus building on goals and actions required for participatory development (Table 3).

\section{Acquisition of social-ecological and economic data}

For each location, the historical, socio-cultural, and anthropological characteristics of the local society and its knowledge of the environment, the distribution of natural resources, folk classification, and management (Tanimbar: Purwanto et al. 2004; Beforona: Pfund 2000; Mahakam: Levang 2002) were studied in parallel with biophysical and ecological studies (Tanimbar: Persulessy et al. 2004, Lidon and Kartiwa 2005; Beforona: Brand 1998, Pfund 2000; Mahakam: Hopley 1999, Creocean 2000). Special emphasis was given to the documentation of traditional ecological practices used by societies: for example, resource extractive activities, the maintenance of services provided by ecological systems (water supply, flood control, soil preservation, biodiversity), attempts to replicate or imitate natural systems (traditional agroforestry), and general traditional knowledge regarding the sustainable management of resources.

GIS databanks, including remote sensing images and aerial photographs, were used to integrate spatial data and facilitate visions of past and present environmental issues (Tanimbar: Jewell et al. 2006, Laumonier 2006; Beforona: Brand 1998; Mahakam: Bourgeois et al. 2002). Maps generated from the GIS databases were bridged with spatially relevant participatory information provided by communities and used as critical tools for commonground discussions. The resulting participatory maps promoted the interactive participation of stakeholders in dealing with spatial information and facilitated effective communication, common visions, and decision-making processes between local communities and government.

Participatory rural appraisal and household survey techniques were used in the community research and information-gathering process (Pfund 2000, Bourgeois et al. 2002, Shantiko et al. 2004). Participatory rural appraisal focused on the generation of collectively agreed-upon descriptions of actual conditions within the community and local government, whereas surveys helped to improve the understanding of socioeconomic and ecological dimensions at the household level. In the case of Mahakam, a commodity chain analysis (Bourgeois and Herrera 2003) was used to study relationships between shrimp farmers, traders, and cold storage companies.

Fostering stakeholders' involvement and building consensus

To initiate a negotiation process and to improve the relevance of the results in building consensus, stakeholders from all parties concerned by the development were identified and consulted from the start at regular participatory stakeholder expert meetings using the proactive conciliation tool, or PACT method, developed by Jésus and Bourgeois $(2002,2003)$ in the Indonesian cases. This method helped to develop a common understanding of the current situation and evolution of the problems and to begin the construction of collective agreements on resource management and planning.

Back-and-forth processes of interaction between the study teams and stakeholders were implemented. These relied on continuous dialog between the stakeholders facilitated by the generation and sharing of findings. All actions emphasized participation, capacity building, transparency, and accountability as the keys to the successful integration of external and local perspectives. The communities were collectively involved from the start of the process. Social-ecological information was shared; training was given not only to local technical agencies, but also to village people. The latter helped to strengthen village land use and natural resource management planning capabilities, to build a stronger local team able to apply participatory methodologies, and to spread the concept further in other villages. Enthusiasm and resulting participation were further encouraged by fostering the willingness to cooperate in providing information through either group discussions or one-on-one discussions and interviews and in providing access to other development actors.

Common vision and shared direction are critical for successful management. Participatory prospective analysis techniques were developed and used for this purpose in the Indonesian cases (Bourgeois and Jésus 2004, Astawa et al. 2006). In Madagascar, the results of systemic analyses (Messerli and Pfund 1999) and synthesis reports (Hurni and 
Table 3. Supporting data and sampling characteristics for the three case studies.

\begin{tabular}{|c|c|c|c|}
\hline $\begin{array}{l}\text { Data or sampling } \\
\text { characteristic }\end{array}$ & Tanimbar (Indonesia) & Beforona (Madagascar) & Mahakam Delta (Indonesia) \\
\hline $\begin{array}{l}\text { Land cover maps and } \\
\text { stratification }\end{array}$ & $\begin{array}{l}\text { LANDSAT Thematic } \\
\text { Mapper satellite data; } 1996 \text {, } \\
2002\end{array}$ & $\begin{array}{l}\text { Aerial orthophotographs; } \\
\text { 1957, 1968, 1987, } 1994\end{array}$ & $\begin{array}{l}\text { LANDSAT Thematic Mapper } \\
\text { satellite data; 1992, 1996, } \\
\text { 1999, } 2001\end{array}$ \\
\hline Ecological data & $\begin{array}{l}\text { Vegetation: } 15 \text { sites, } 75 \text { plots } \\
\text { of } 0.2 \text { ha } \\
\text { Soil: } 75 \text { sites and } 450 \\
\text { samples }\end{array}$ & $\begin{array}{l}\text { Vegetation: } 252 \text { plots of } 0.03 \\
\text { to } 0.08 \text { ha } \\
\text { Soil: } 160 \text { samples }\end{array}$ & $\begin{array}{l}\text { Secondary data from Hopley } \\
\text { (1999) and Creocean (2000) }\end{array}$ \\
\hline Socioeconomic data & $\begin{array}{l}15 \text { village studies (population } \\
\text { of } 500-2500 \text { ) using an in- } \\
\text { depth socioeconomic survey } \\
\text { of } 450 \text { households for } \\
\text { indicators such as access to } \\
\text { land, agricultural techniques } \\
\text { and calendar, and household } \\
\text { economy (see Shantiko et al. } \\
2004 \text { ) }\end{array}$ & $\begin{array}{l}6 \text { village-level appraisals and } \\
\text { a survey of } 42 \text { households for } \\
\text { indicators such as access to } \\
\text { land, agricultural techniques } \\
\text { and calendar, and household } \\
\text { economy (investment in time } \\
\text { and benefits from different } \\
\text { land uses) }\end{array}$ & $\begin{array}{l}50 \text { respondents for } \\
\text { stakeholders' typology; a } \\
\text { survey of } 100 \text { households for } \\
25 \text { socioeconomic indicators, } \\
\text { including pond operation, } \\
\text { economics, and technology; } \\
\text { in-depth interviews of } 30 \\
\text { shrimp traders }\end{array}$ \\
\hline Socio-cultural & $\begin{array}{l}15 \text { villages; extensive } \\
\text { interview of elders and } \\
\text { customary and religious } \\
\text { leaders }\end{array}$ & $\begin{array}{l}6 \text { villages; extensive } \\
\text { community appraisal and } \\
\text { interview of elders and } \\
\text { customary leaders } \\
\text { (genealogy, local rules, } \\
\text { sacred sites) }\end{array}$ & $\begin{array}{l}\text { Extensive interview of elders } \\
\text { to track the evolution of Bugis } \\
\text { settlements in the delta }\end{array}$ \\
\hline
\end{tabular}

Ramamonjisoa 1999) were used to gather stakeholders and catalyze collaborative strategies at local and national levels through a series of meetings and workshops. We discuss the comparative results using the following common analytical structure: local perceptions and use of the environment, land use changes and disturbances, and steps toward participatory development.

\section{LOCAL PERCEPTIONS AND USE OF THE ENVIRONMENT}

\section{Tanimbar, Indonesia}

Sovereignty based on common property rights is central to Tanimbar society and occurs at three levels: household, clan (marga), and soa (a group of marga). The management of customary land (petuanan) is based on the "eating together" sharing principle. Land is not owned by individuals, but the cultivation rights can be passed on to the next generation. Within the petuanan, the traditional system for managing natural resources is known as sasi. This system, criticized for not being fully equitable (Zerner 1994), nevertheless regulates the period of use of natural resources such as forest, sea, and plantations. It is based on mutual benefits and strengthens social cohesion (Novaczek et al. 2001, Purwanto et al. 2004). Tanimbar societies today are still highly obedient to sasi rules.

Resource-based activities (agriculture, fisheries, and foresty) represent $>70 \%$ of the population's income. In addition to the production of copra (dried coconut), people cultivate vegetables, corn, upland rice, and tubers according to the season and use little chemical fertilizer. Livestock such as pigs, goats, and chickens mostly represent savings. Depending on the season, fishing also provides substantial additional income for households. Other valuable marine products such as sea cucumber and top shells 
(Trochus spp.) are traditionally managed under sasi and are looked after very cautiously. Nontimber forest products represent $8 \%$ of the total income, which is twice the contribution of timber. Since the local ban on industrial logging in 1992, wood extraction has been essentially community based.

Our investigations indicate that $>350$ species are used in all aspects of daily life. The indigenous knowledge of the landscape itself recognizes several land cover and land-use units associated with good soils for agriculture. The communities also have a clear representation of the spatial allocation of landuse rights and a clear understanding of the relationships between deforestation and changes in the condition of the natural resources such as water availability and quality.

\section{Beforona, Madagascar}

In Beforona, the dominant ethnic group, known as the Betsimisaraka, has maintained a strong cultural identity and indigenous knowledge in rural areas. Farmers are very knowledgeable about the different types of vegetation and use indicators such as leaf color to evaluate soil fertility. Half of the 750 plant species listed by Pfund (2000) have a local use, and $>100$ are commonly used. The core production system, a slash-and-burn practice locally known as tavy, has been handed down from generation to generation. Fallow and upland rice fields cover approximately $60 \%$ of the village territories. This system is anchored in cultural values related to the veneration of ancestors and their practices. Access rights to the land fall roughly into three categories: community rights, especially for land dedicated to special harvests for the celebration of ancestors, in places called sembotrano (clothes of the ancestors); kinship group rights; and rarer access for households alone when land has been "privatized" from kinship lands.

The burning of slashed vegetation is considered important by local people because it is supposed to warm the soil and eradicate pests such as rats. The preservation or longer duration of fallow periods combined with more restricted access has resulted in sembotrano being less degraded than the surrounding areas. Farmers also follow some agricultural practices relevant to sustainable management. They use fire-breaks and burn the fields according to wind direction to avoid uncontrolled wildfire. When weeding rice fields, they spare useful woody species. At the landscape level, they maintain sacred riverine and hilltop forests. Households, especially within kinship groups, try to concentrate their properties along secondary valleys or microwatersheds because these allow crop diversification, as well as easier access to and control of fields and forest, than do other areas.

\section{Mahakam Delta, Indonesian Borneo}

In the Mahakam Delta, no customary law controls access to the area and its natural resources, which is under the responsibility of the Ministry of Forestry and is classified as swamp forest. Local forestry services do not view the Mahakam Delta as a valuable asset because of the dominance of Nypa palms over mangrove tree species. Land allocation by local village rulers was not an issue when the population of fishers first settled. The only ecological practice that was tacitly respected was that of keeping a protective mangrove belt separating the ponds from the sea or riverbanks.

\section{LAND USE CHANGES AND DISTURBANCES}

\section{Tanimbar, Indonesia}

In Tanimbar, the more traditional remote villages of the west contrast with those on the east coast. In the east, customary territories are smaller, the topography is steeper, river basins are short, and the risk of ecological decline, erosion, and land conflicts is higher. In the south, closest to the main city, a shortage of access to new land has already resulted in a degraded landscape largely dominated by invasive species like bakurang (Chromolaena odorata) as a result of overfarming and burning. The building of new roads also created new pioneer fronts, as can be observed along the Saumlaki-Arui east coast road.

Starting in the early 1990s, a logging company operated for $2 \mathrm{yr}$ and then left the area because of the severe social turmoil its activities created among the local people. The social and environmental effects of this commercial logging brought considerable national and international attention and resulted in an unprecedented decision: the suspension of logging operations on Yamdena Island. Of great concern was that communities were 
not given any representation within the planning process and that traditional land- and forest-use rights were being effectively ignored in favor of profits from commercial timber production. Apart from the social issues, a particular environmental worry of scientists was the effect of commercial logging activities on soil types that have very high potential erosion rates under seasonal climate. Since then, several attempts have been made by timber companies to reopen concessions, thus far unsuccessfully.

With such a high level of forest cover, which includes high-value timber species, but with a strong communal sense of ownership for ancestral lands, the potential for future conflicts over the use of forest resources in Tanimbar is very high. A participatory approach was advocated to help avoid conflicts in the design and implementation of new natural resource management plans.

\section{Beforona, Madagascar}

In Beforona, the road linking the harbor of Toamasina to Antananarivo is strongly influenced by the history of human settlement and agriculture. At the beginning of the 20th century, colonial programs promoted coffee and other cash crops in the region, leading to an agricultural landscape dominated by upland rice, coffee, and banana.

Farmers first cleared fields in the more fertile valley bottoms and built villages close to the rivers. Nowadays, where remote forest is still accessible at higher elevations and on more fragile soils, farmers who are short of land still use the same techniques. Only rocky land on hilltops is avoided. Elsewhere, labor constraints and social aspects encourage farmers to keep their fields as close to their dwellings as possible. The fallow duration is the first parameter to be modified under increased demographic pressure. Outside sembotrano, farmers have reduced fallow periods to an average of $5 \mathrm{yr}$. As forest disappears, the nutrients stored in the vegetation are lost. The distributions of invasive weeds expand, increasing labor needs and constraining investment in other activities. Finally, aluminum toxicity and changes in soil texture make it impossible to cultivate rice (Fig. 1).

Rice is grown mainly for self-consumption, but is sometimes used for urgent cash needs. The loss of productive soils and the resulting decrease in upland rice production forces farmers to both extend rice fields and cash crop production areas. For monetary income, farmers are worried by the instability of banana and coffee prices.

A noticeable shift in cultivation strategies occurred during the 1990s. Highland migrants were allowed to found new villages through alliances. They cultivated ginger and developed commercial networks. Because of good economic returns, they were soon copied by local farmers. In 1998, ginger production became the second most important household activity in terms of labor investment. This wide and rapid adoption of ginger production had negative ecological effects that were stronger than those under the tavy system. In particular, the need to till the soil to grow ginger makes fields more prone to weed invasion and nutrient leaching.

\section{Mahakam Delta, Indonesian Borneo}

Oil and cold storage companies began operations in the Mahakam Delta in the mid-1970s. The influx of workers created a new market for local products, especially fish and seafood. By introducing the local black tiger prawns (Penaeus monodon) to the international market and by lending capital to selected fishers, cold storage companies dramatically changed the local economy.

The prohibition of trawl fishing by the Indonesian government in 1980 led fishing communities to experiment with ponds. In the 1990s, excavators progressively replaced manual labor; shrimp farming turned from a small-scale family activity into an industrial business. From 1995 onward, immigration peaked and shrimp ponds expanded tremendously. The 1997-1998 monetary crisis trebled the local value of the shrimp while input costs remained unchanged (Fig. 2). In 2002, 75\% of the area was covered by productive ponds or ponds in preparation, whereas most of the Nypa area had disappeared. Ponds even encroached upon the upstream freshwater swamp forest.

The delta became a wealthy area. Some of the poor migrants from the 1970s today exploit thousands of hectares of shrimp ponds. The natural fertility of the delta produced immediate returns, and the net value of shrimp production, which was almost nil in the early 1970s, reached US\$ 100 million in 2001 (Bourgeois et al. 2002). Shrimp farming intensified through the increased use of inputs and mechanization. 
Fig. 1. Effects of repeated slash-and-burn cultivation practices on vegetation and the carbon and nutrient contents of soil and vegetation. The average effect of the repeated slash-and-burn cultivation cycle (generally $1 \mathrm{yr}$ cultivation, $5 \mathrm{yr}$ fallow) on carbon and nutrient stocks (nitrogen, phosphorus, potassium, calcium, and magnesium) can be measured in vegetation and soils along a degradation gradient from rain forest to shrub fallow, mixed fallow, degraded fallow, and grassland (Brand and Pfund 1998). The time taken to pass from one stage to another is approximate, based on interviews with farmers about past cultivation cycles. The first threshold is the transformation of forest into agricultural land. The organic matter in the soil increases, but the nutrients stored in the vegetation are mainly lost. The second threshold is the appearance of invasive species. The third threshold is decisive because the soils become depleted and it is impossible to cultivate rice, mainly because of changes in texture and aluminum toxicity.

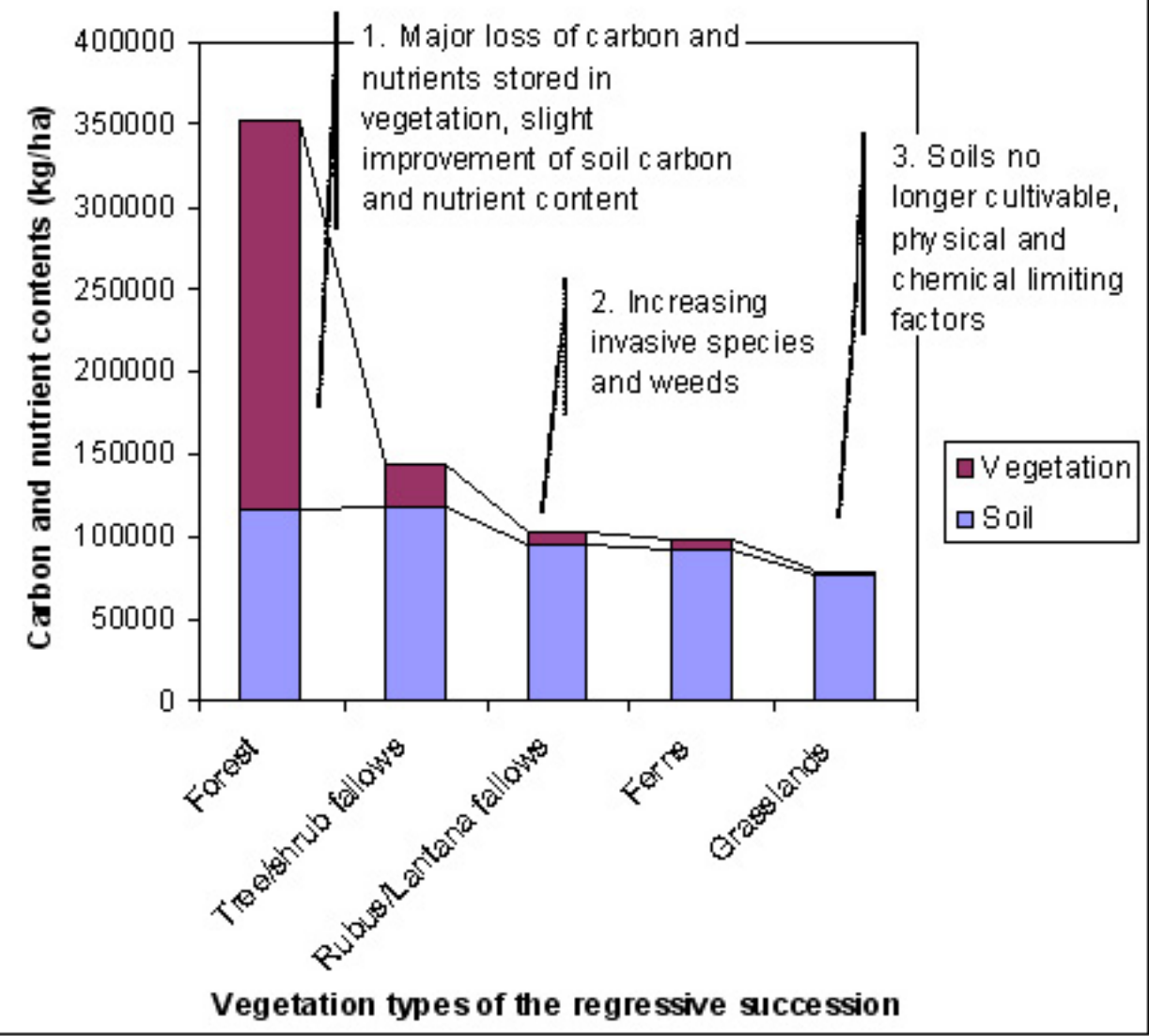


Fig. 2. Land cover and land-use change in the Mahakam Delta (1992-2001), after Bourgeois et al. (2002).

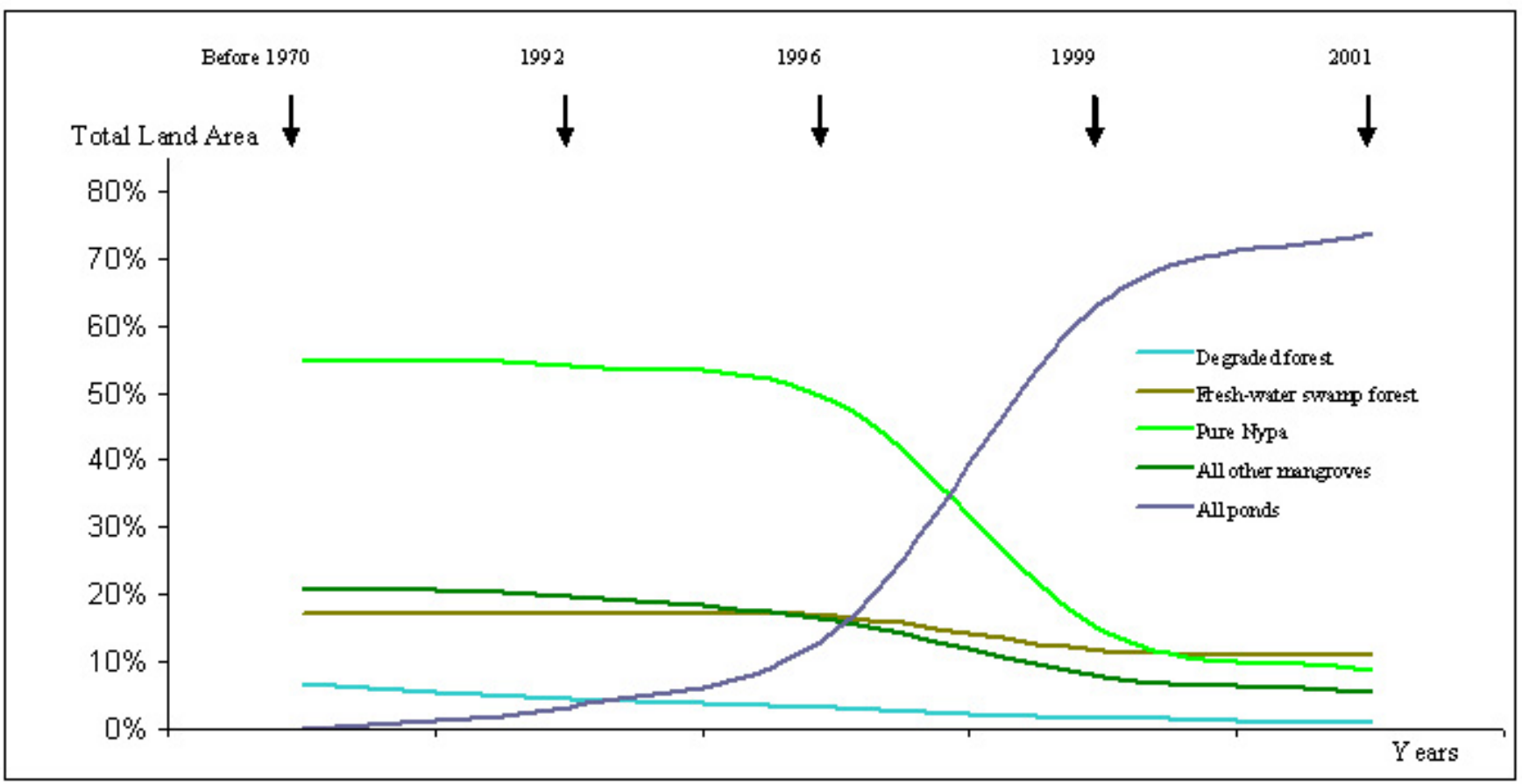

Rapidly, problems of soil loss, decreasing pond productivity, dyke erosion, and shrimp diseases emerged. The functions and values of the mangrove forest disappeared, in turn threatening shrimp farming. Like elsewhere, shrimp ponds are the indisputable cause of the destruction of the mangrove forest (Macintosh and Zisman 1997). The average production of black tiger prawns was $80 \mathrm{~kg} /$ ha in 2002 compared to reports of $600 \mathrm{~kg} / \mathrm{ha} 10 \mathrm{yr}$ earlier. Total harvest failure has also occurred. The system lacks sustainability, and the threshold of ecological sustainability was already transgressed in approximately 1996-1997 (Fig. 3). Shrimp production on a large scale experienced its wellknown boom-and-bust cycle (Spaninks and van Beukening 1997, Primavera 2000, Hein 2002, Huitric et al. 2002), resulting in its own collapse, as well as the total destruction of the environment.

By 2000, no land was available for further shrimp pond development, and competition for land often turned into conflict. Conflicts expanded and linked the shrimp and oil sectors: shrimp farmers claimed that the activities of the oil companies caused the production losses that they were experiencing. Local environmental nongovernmental organizations entered the game, mostly supporting the shrimp farmers' claims. Finally, the local government tried to intervene after witnessing the degradation of the mangrove forest, the rising conflicts, and the economic loss caused by failing shrimp production, which had been a major source of income.

\section{STEPS TOWARD PARTICIPATORY DEVELOPMENT}

\section{Tanimbar, Indonesia}

In Tanimbar, the shortcomings of the old land allocation maps and plan were acknowledged by the parties involved, and a participatory research and development program was established to promote and facilitate the integration of local concerns and national priorities in a new land-use plan. The stakeholders' involvement culminated in a series of 
Fig. 3. Evolution of the ratio of shrimp ponds to mangrove swamp and the ecological footprint threshold. The ecological footprint line (Rees and Wackernagel 1994) represents an estimate of the productive land and water area required to supply the resources that a human activity demands, as well as to absorb the wastes that it produces. The line is thus a sustainability indicator. It is drawn here at a ratio of 1:2 (1 ha of shrimp pond requires 2 ha of mangrove swamp), using references to shrimp aquaculture in Asia and Colombia (Kautsky et al. 2000).

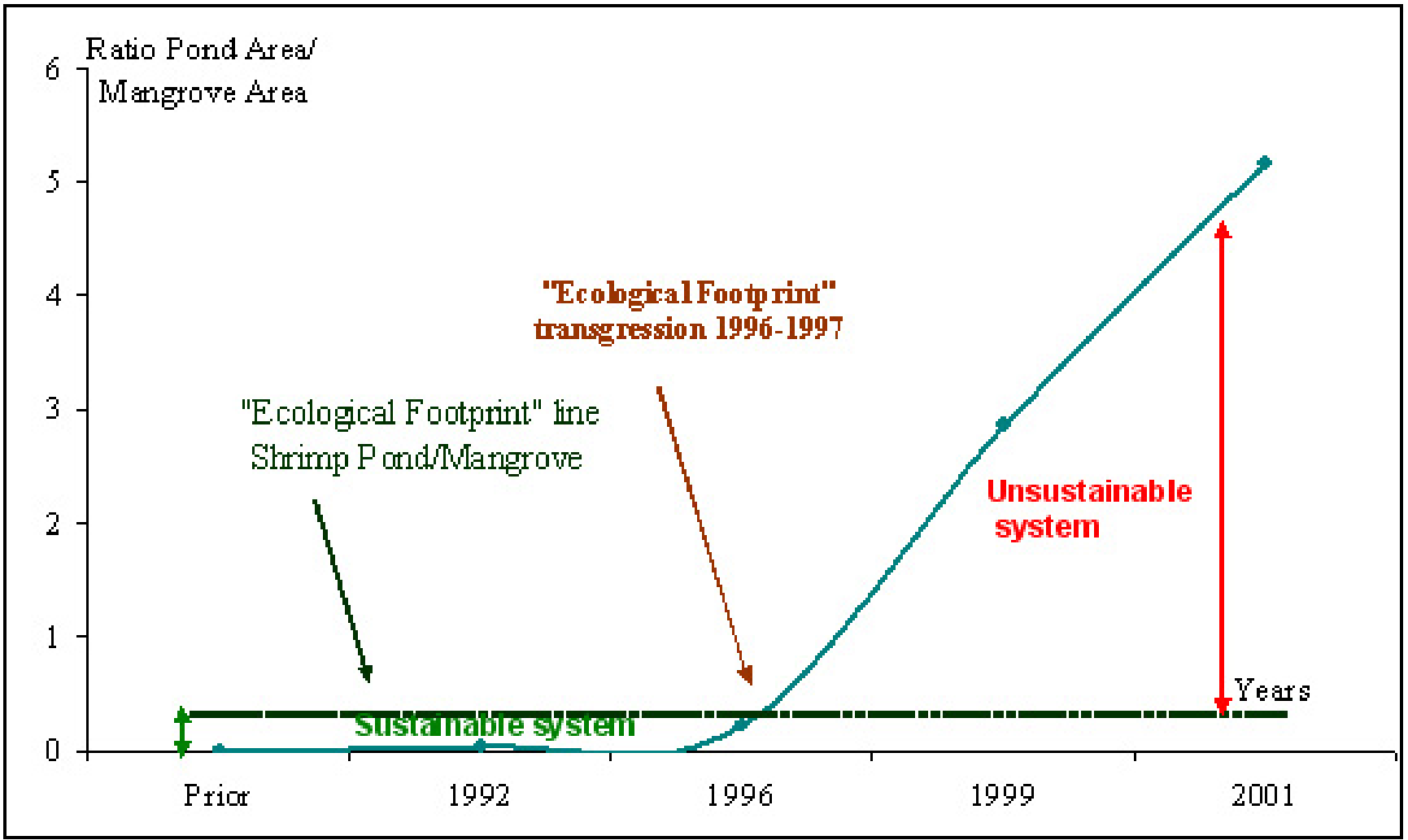

workshops at which the results of the study were debated. The final recommendations, endorsed by the local government, were presented to the local legislative assembly and provincial government to strengthen the legitimacy of the official request made to central government. There were three main consensuses.

The first consensus emphasized the importance of traditional resource management mechanisms and the necessity to promote them for integration into statutory law. Potential conflicts related to the petuanans' borders between villages were identified. Legal action has proved to be unsatisfactory because modern law brings only more distrust and feelings of unfairness. On the contrary, conflict managed by means of adat (customary) law and consultation involving a pela (mediatory village) usually helps to satisfactorily settle intervillage disputes. However, its implementation remains difficult in the modern world when it is not recognized by the central government.

The second consensus concerned land allocation and land-use planning agreements reached through milestone events, facilitating the development of a common vision on the future of forest and land use. These agreements were achieved through three steps. The first was a series of participatory prospective analysis workshops to share knowledge, discover triggering factors that may influence possible development scenarios, and choose actions 
to anticipate the triggering factors. This led to the South Yamdena community workshop in which representatives of the 15 villages provided recommendations for the formulation of policies on the management of natural resources. The final workshop included all 40 Yamdena villages, project participants, and government to reach agreements about natural resource management, revise the land status and forest function maps, and formulate new official documents.

The third consensus was another mutual agreement between communities and local government on future actions in the agriculture, forestry, and fishery sectors. Two workshops were organized to collaboratively decide what kinds of rural development project would be acceptable to all parties. A consensus was reached on communitybased development projects designed for joint management with local technical agencies for forestry, agriculture, and fisheries (Astawa et al. 2006, Laumonier 2006).

\section{Beforona, Madagascar}

In parallel with nationwide programs on participatory conservation (Hannah et al. 1998) and initiatives on devolving management power to local communities (Bertrand 1999), the study has opened the way for more action on participatory development through a multidisciplinary understanding of the situation in the region of Beforona. Despite the political wish to eradicate it, tavy remains steadfast, and associated ritual rules are maintained as long as they do not require too much financial investment. Land-use and agricultural practices appeared to be very sensitive to demographic pressure and poverty. Environmental degradation and the lack of forestland have resulted in the greater importance of tanimboly, the home-garden system for cash crop production and off-farm opportunities.

We found that migration was a key parameter in the social cohesion of villages. Generally, the integration of individual migrants poses no problem and is rather welcome through family alliances. The integration of full migrant groups is more difficult. Such groups are more inclined to reside in a part of the village, rather than to integrate. When conflicts arise, the solution is simply for part of the population to leave and build a new village. Migrants are expected to respect the local rules and to follow the traditional farming system. In the studied villages, customary rules related to family and community were generally respected, but traditional practices or bans related to resource management were not effectively suggested or imposed, with even a few cases of exploitation of sacred forests by migrants.

Aware of the degrading conditions and looking for innovations, communities were keen to collaborate, and agreements between farmers and scientists led to the selection of priority activities and trials such as a direct-seeding mulch-based cropping system. This was followed by the relatively successful introduction of an "ecologically friendly" ginger, $i$. e., ginger cultivated together with leguminous species and planted on contour lines to improve fallow lands. The gain in biomass was approximately 8 metric tons/ha, $40 \%$ of erosion was avoided, and economic returns increased by 18 30\% (Messerli 2006).

Finally, despite these innovations, the fact that the tavy system was so central to community livelihoods and that appropriate alternatives to growing upland rice were still impractical needed to be heard at the central level. National workshops for the government, policy makers, technical agencies, and community representatives were organized to help understand better the realities of this traditional system when planning development activities.

\section{Mahakam Delta, Indonesian Borneo}

In the Mahakam Delta, the participatory action research enhanced interactions among stakeholders and set the ground for the design of an integrated resource management plan. It succeeded by providing a better understanding of the ongoing dynamics. A key element was the generation of shared data on the evolution of the delta and its current situation based on the identification of individual and collective perceptions, socioeconomic and technical indicators of the shrimp business, links and strategies of the actors in the supply chain, and the visualisation of land cover change and estimates of erosion.

Stakeholders' involvement culminated in workshops at which findings were presented at various stages. During these workshops, the participants agreed on the creation of a new organization comprising representatives of all stakeholders in the Mahakam Delta and on the collective design of an agreed-upon 
land-use scheme along with land access regulations. The district authorities agreed to take the lead to make the regulations operational. A task force started to operate, and the workshop conclusions were presented to the local legislative assembly.

Despite the momentum created, no activities were implemented for $2 \mathrm{yr}$. The United Nations Development Programme then supported scientists and local nongovernmental organizations in designing a strategy to strengthen stakeholders' coordination for the integrated management of the delta resources. The resulting proposal (Bourgeois et al. 2004) aimed at empowering local stakeholders in establishing an economic and ecological balance that would ensure sustainable economic activities in the delta.

\section{DISCUSSION AND LESSONS LEARNED}

All three cases initially aimed at facilitating mutual social-ecological understanding among local government, local communities, and other stakeholders regarding the implementation of landuse and management practices that are compatible with the natural, socio-cultural, and economic potential of the areas. We next discuss how the ecological dimension of development was perceived by local societies and to what extent the participatory development initiatives have enhanced the fit between ecological, socio-cultural, and economic systems, leading to some common lessons learned.

\section{Local perceptions of the ecological dimension}

Our studies confirm that the ecological dimension remains weakly or awkwardly addressed. It is vague for most parties and difficult to integrate into development actions when dealing with tropical forested landscape management in developing countries. We examine three issues to understand why this is the case: the disdain for traditional ecological knowledge and practices, the antagonism between economy and ecology, and the mismatch between traditional and modern governance systems.

\section{Disdain for traditional ecological knowledge and practices}

Most traditional societies are thought to have developed ecological knowledge as systems of local conservation (Berkes et al. 1998). However, the debate is not closed on the real effectiveness of indigenous conservation and how to translate and use this knowledge in the implementation of natural resource management and development actions. If an ecosystem-like concept exists in traditional society, what is the kind of change that traditional ecological knowledge can withstand? To what kind of change is it more vulnerable, and what aspects of it should be implemented in modern rural development, instead of only being documented by scientists? Our study confirms that in Indonesia and Madagascar, relevant traditional indigenous knowledge related to environment and ecosystems exists, but is largely ignored or rejected by planners and governments.

The sasi in Tanimbar is a good example of an adaptive management system based on traditional ecological knowledge. It is still effective, although the extent to which it is applied varies. It focuses more on coastal environments than inland forest and vegetation. Although it seems resilient in Tanimbar, it has been obviously weakened by conflicts with the official system in many other parts of the Moluccas, and it has not been able to adapt to the changing economic and political environment in which it operates. Good ecological practices are still documented for Tanimbar, where communities traditionally have a sustainable system for extracting resources from the forest, maintaining forest cover around water springs, managing wildlife populations and semi-domesticated forest species, and establishing traditional agroforestry systems near the village. However, our study shows that this traditional knowledge is disregarded by local governments and planners and is even difficult to discuss at the central level.

Knowledge of plants still remains in Beforona, and farmers use various forest products, but no local strategies could be identified that aim at sustaining this forest production. Farmers essentially appreciate the forest as a land reserve for rice cultivation and manage to substitute a majority of forest products with secondary vegetation or planted species. Once the forest is converted into agricultural land, it will not return to the original vegetation for all of the abovementioned ecological and socioeconomic reasons. The tavy is seen as an unsustainable and outdated practice by government and many scientists. Although the disdain for this practice is high, our study showed that it remains a system linked to cultural aspects and constrained by local biophysical characteristics. Notably, the fact 
that there is no tillage so that protective vegetation cover is always present minimizes the effects of the frequent cyclones on soil erosion and nutrient leaching.

In the absence of preexisting ecosystem knowledge in the Mahakam Delta, economic opportunities alone shaped the path that transformed the original delta into a gigantic shrimp farm. The only factor limiting total transformation was the harsh environment.

\section{Antagonism between ecology and economy}

The importance of a landscape to communities is dictated by its potential benefits (Cunliffe et al. 2007). The level to which an existing traditional natural resource management system is exposed to economic pressures and the system's degree of social cohesion combine to explain how fast the traditional knowledge of the environment weakens in the face of economic development.

Where a strong customary system still prevails, like in Tanimbar, local communities have been able to control the pace of change to a certain extent. However, the building of a new asphalt road from the capital city has immediately induced the development of new transportation services and the diversification of market activities at the nearest villages. The overwhelming number of villagers involved in wood extraction has led, in a $10-\mathrm{yr}$ period, to the overexploitation of the most valuable species in the south of the island. This shows how fragile traditional environmental sustainability practices can be in the face of economic interests.

When demographic pressure and the arrival of migrants put pressure on the land, as in Beforona, community cohesion is reduced. Although the resilience of the tavy system, which has been a permanent concern for government authorities, is undeniable, it has finally given way to new practices that are no longer in line with traditional agricultural practices. Originally anchored in multidimensional sustainability goals, this knowledge did not lead to noticeable preventive strategies or innovations with regard to ecological degradation. Reactions were only observed when the benefits were directed outside the community or when the system became unproductive.

In the Mahakam Delta, waves of migrants have successively shaped the landscape as it fitted their economic interests. The negative ecological effects did not bother the stakeholders, at least not until the risk of economic collapse became apparent. It was only when ecological degradation started to affect the economy of shrimp production and to threaten livelihoods that people reacted. To some extent, the direct effect on the household economy induced the emergence of some environmental awareness. This confirms that in the antagonism between economics and ecology, the former regularly prevails over the latter.

This preeminence of economic forces in all situations raises the issue of the absence of marketbased environmental incentives that would encourage the local population to improve their farming systems through the adoption of more sustainable agricultural innovations. In Beforona, for instance, the rapid development of ginger cultivation indicates that farmers are able to adapt to new niche products. However, at the same time, we found that they will definitively not abandon tavy, which is a livelihood guarantee against risks linked to the new challenges of finding traders and facing uncertainties in the evolution of new markets. They will also keep their extensively managed home-gardens, which are never converted to other uses, even in periods of low prices. Risk management remains a central aspect of rural strategies. As is often observed, innovations generally have to be well integrated into traditional systems in terms of techniques and time requirements, as illustrated by the case of ginger cultivated on fallow normally used for upland rice. In the Mahakam Delta, some cold storage companies began to experiment with fishery systems that incorporate mangrove tree species planted in and around shrimp ponds. Our interviewees indicated that this decision was partly related to the request for more environmental friendly practices by potential buyers from European Nordic countries.

\section{Mismatch between traditional and modern governance systems}

Local communities in Tanimbar requested support for the integration of environmentally sound traditional rules within the official rules of natural resource management to give them authority and legitimacy when dealing with problems affecting the community environment; however, it was a very challenging issue to obtain this support. The integration of customary laws into national law and 
juridical systems could increase the possibility of reaching better law enforcement and conflict resolution agreements. In turn, combined systems of traditional and statutory laws will become more legitimate for the resolution of local conflicts. It seems that no significant improvement in the local resolution of conflicts between customary and statutory laws can be expected unless such a national integrated legal system is put into place. The suggestion is not new (Hooker 1978, Colchester 2006), but the national legal framework in Indonesia does not facilitate such ideas because customary rules are believed to be too site specific.

In the Beforona region, an important effort to register land tenure has been conducted during the life of the action research. Common lands were registered according to traditional village access rules. Despite the appropriate approach, the initiative has had no clear effect on either deforestation or development because conflicts for tenure are not yet local issues. Mining sector pressures have become more important in the country, and comprehensive efforts are now being pursued with the support of the World Bank to register and secure local rights. Other approaches that take into account traditional rules or use traditional governance models with regard to natural resource management and land tenure (dina) have been proposed for Madagascar. The gestion locale securisée (secured local management), or GELOSE, initiative (Bertrand 1999, see also the synthesis on $10 \mathrm{yr}$ of impact by Montagne et al. 2007) is based on formal agreements between the Communes, the State Forest Service, and local communities, including rules for the use of selected common natural resources and to ensure management rights for local communities. These conservation-oriented initiatives have generally targeted forest surroundings and protected areas. The GELOSE initiative is a very challenging process that mainly relies on external projects and still remains difficult to scale up and monitor. Its sustainability was questioned at the implementation phase (Maldidier 2001) because of the lack of direct benefits from or incentives for sustainable management and also for its weaknesses in terms of monitoring and enforcement. Rules lose their power to influence behavior if not accompanied by proper enforcement mechanisms (Horning 2005).

Although no traditional governance system controlled access to resources and ecological practices in the Mahakam Delta, rules of land allocation and appropriation were developed locally. These rules stemmed from the original practices of the migrant population. As in the other cases, when local authorities started to intervene, they disregarded the existing practices and related rules and tried to impose blueprint land-use planning schemes based on external expertise. The socialization of these plans did not succeed for two reasons: the disparity between the plans and the existing reality and the lack of enforcement capacity.

\section{Lessons learned about the local perception of the ecological dimension}

Some common lessons can be drawn from our analysis. Communities are not encapsulated in a traditional, stubborn, conservative pattern of behavior. They are open to change, especially if this means economic opportunity. In Tanimbar, strong community values embedded in the sasi system give mutual assistance high priority. Environmental concerns are strongly expressed. However, all of the projects selected by the community are directed toward the generation of new economic opportunities. In Beforona, the tavy system has inherent logic that fits with local conditions and is also embedded in the local culture. However, an alternative system, the cultivation of ginger, has spread more widely among farmers than any government intervention could have dreamed because of its economic attractiveness. The fact that it has a potential negative effect on the soil indicates that economic values can very quickly take over social and ecological values, especially when demography increases pressure on lands and external agents (here migrants) bring sudden changes. This is further confirmed by the case of the Mahakam Delta. However, this case paradoxically supports the point of openness to change. As observed elsewhere in South Kalimantan (Vayda and Sahur 1985), the length of time that Bugis migrants intended to stay was determined by the profits that their activities would yield. Profitability, rather than sustainability, guided local resource use, resulting in a lack of longterm local commitment. However, some migrants have been settled in the delta for decades and progressively formed local communities. Having abandoned the mobility that would explain a disregard of the impact of their economic activities on the environment (Vayda and Sahur 1985), some of them now display a sense of heritage about their land. They are ready to move from extractive 
practices guided by short-term economic profit that are typical of Bugis values of entrepreneurship to more sustainable livelihoods. Technical solutions that are not integrated in a broader vision of education, off-farm employment, rice production, and stable or even subsidized cash-crop markets, as well as support for village authorities, will not significantly affect the traditional systems.

\section{The role of participatory development in enhancing the fit between ecological, socio- cultural, and economic systems}

Local communities, government, technical agencies, and scientists often have substantially divergent views on conservation and priorities for development. Participatory development as practiced in the three cases discussed here showed potential to enhance the fit among ecological, sociocultural, and economic systems through two dimensions: the generation and sharing of information to understand trends and the generation of new coordination practices that enable stakeholders to voice environmental concerns. We next discuss the extent to which these dimensions actually contribute to the fit across the three cases.

\section{Generating and sharing integrative information to understand trends}

Without a long-term collective vision about the management of natural resources, local communities are often placed in a weak position in the face of third parties that are driven by pure economic interests. In the absence of such a vision, existing rules to control resource usage by communities can be easily bypassed. The elaboration and dissemination of multidimensional analyses and results among stakeholders, particularly updated information about ongoing changes and projected impacts, play a key role in the emergence of this type of vision. Multidimensional information includes not only changes in the environment, but also in socioeconomic conditions, to understand trends, particularly those that threaten the stakeholders' livelihoods. This is powerful leverage to entice stakeholders to acknowledge past realities and to act accordingly.

New coordination practices for voicing ecological concerns

The communities in Tanimbar have expressed environmental concerns for the future, especially linked with the quality and shortage of water and the shortage of timber already experienced on neighboring islands; thus, they have agreed on the strategic aspects of natural resource management and land-use planning at the village and customary land levels. They are willing to further develop new land and water conservation rules together with the local government. However, they do not consider ecology alone and also express hopes of obtaining economic and legal support for activities that would promote a more market-oriented development of their farm products: the constitution of cooperative farmer groups to revitalize the spirit of mutual assistance among community members, as well as to provide a forum for the development of future participation; and the establishment of legal decrees for regulations on the management of natural resources at the village level that are not in conflict with national law.

In Beforona, improved knowledge about the views and perceptions of rural populations has highlighted shared interests and contradictions and thus has built the foundation for negotiations. Traditional ecological knowledge has given information about potential management processes that have been tested with relative success. However, even some clearly improved techniques have proven to be dependent on market fluxes and shocks. In some cases, effective solutions will not only be linked to the management of natural resources, but also to social cohesion and off-farm opportunities, as indicated by some communities. Participatory processes have helped to place ecological concerns into broader perspectives.

In the Mahakam Delta, coordination practices evolved from loose top-down consultation with local authorities with the purpose of "socializing" decisions to multistakeholder platforms where information was built together and shared. Bipartite discussions between local authorities and the oil companies gave way to arenas where all stakeholders were represented, including nongovernmental organizations, local village leaders, shrimp farmers, and traders. These new coordination mechanisms included mixed-group discussions and contributed to the emergence of a common vision of current problems and the rise of an ecological awareness that crystallized through information campaigns via radio and television broadcasts and the large-scale dissemination of brochures and posters targeting specific stakeholders, in particular, cold storage companies, shrimp traders, and shrimp farmers. As a result, the ecological dimension of shrimp farming 
was fully embedded as a priority area of work in the design of the Mahakam Delta management plan.

\section{Lessons learned on the role of participatory development in enhancing the fit between ecology and the socio-cultural and economic systems}

In all cases, local communities were keen to collaborate further with external stakeholders. Unfortunately, the means and endorsements are lacking at the national and provincial levels to conduct and adopt more participatory planning strategies to give more confidence to the local population. Collaboration among state agencies, representatives, and local authorities needs to improve to guarantee the guidance and implementation of improvement measures. The step of translating a completed research action project into development actions remains difficult, even using a participatory approach. This information is not completely new, but shows how the gap continues to increase between science on paper and policy making in the development of tropical landscapes. In all three cases, field activities and the involvement of stakeholders created a momentum that one would have expected to be easily turned into the practical implementation of agreed-upon decisions. However, things did not move that easily.

In Tanimbar, the proposed new land allocation and changes in forest function were agreed upon by all parties, including forest services and communities. In 2007, this final output, supported officially by the district head, the regional legislators, and the governor of the Moluccas province (a necessary legal procedure for the Ministry of Forestry to consider the changes requested) was still pending official acceptance by the Ministry of Forestry in Jakarta, with no indication of progress.

In Beforona, after some years of success, interest in ginger cultivation, including "ecologically sound" ginger, has declined. Coffee is again leading the market. At the 2002 World Summit sustainable development conference in Johannesburg, South Africa, the president of Madagascar promised to give the status of Nature Reserve to $6 \times 10^{6}$ ha of forest. The way to reach this goal is still being debated, with more emphasis given to communitybased conservation instead of participatory development action (Andrianandrasana et al. 2005). On the political side, misunderstandings about the tavy system and shifting cultivation remain. The GELOSE process is frozen, with all logging authority that was given to local communities suspended in 2007 because of frauds and abuses. On one hand, studies have put forward the destructive nature of shifting cultivation without acknowledging the resilience of the traditional slash-and-burn cultivation that has occurred in valley bottoms for more than a century (Styger et al. 2007). On the other hand, the ideas are still advocated that local people want to maintain traditional rules by any means and that their practices are justified (Mertz et al. 2008). This persisting dichotomy of perceptions often limits the scope of research and suitable development options. There is a need for better balanced and less subjective interpretations (Hume 2006).

In the Mahakam Delta, going from commitment to action was difficult, even with strong momentum and consensus. Delays were essentially circumstantial, but local political games at the district level and long negotiations among external and national donors also froze the momentum, making it impossible to reach financial and legal decisions before the end of 2006. Finally, a 5-yr, US\$3.6 million community empowerment program supported by the United Nations Development Programme, Total Indonesia, and local and national governments has been launched. Without the commitment of the United Nations Development Programme, even in the presence of some available resources, the output of the participatory development initiative would probably not have been translated into an implemented program.

\section{CONCLUSIONS}

Our comparative study across Indonesia and Madagascar shows that in the absence of a "leader" or "champion," institutions, and financial resources, expected outcomes remain on paper, even when changes have been negotiated. Invariably, it seems that for the ecological dimension to be genuinely taken into consideration up to the implementation of resource management plans, the commitment of an outside facilitator such as a donor institution is critical.

In our opinion, future multidisciplinary research approaches in natural resource management must emphasize better integration of the ecological assessment (Jensen and Bourgeron 2001) and strategic environmental assessment (Dalal-Clayton and Sadler 2005) views, working more closely at 
the interface of ecology and governance. This will lead to emerging challenges such as the design of operational tools to reconcile ecology with social and economic concerns, the creation of governance systems to institutionalize collaborative and integrated resource management, and the design of enabler organizations close to local communities.

\section{Designing operational tools to reconcile ecology with social and economic concerns}

To be closer to reality and to understand better the numerous trade-offs between conservation and development, scientists must not only work with communities, but must develop better links with nongovernmental organizations, local technical agencies, and local and national governments, especially to facilitate capacity building in participatory conservation and development concepts and actions. Although social research and facilitation remain critical, ecological research integrated at the landscape level needs to be reinforced and adapted to policy makers' capacity to absorb it. To deliver relevant information for negotiations, especially when production and conservation interests mutually conflict and when short-term concerns prevail, a stronger emphasis on ecological criteria is critical, in addition to agronomic and socioeconomic research.

\section{Creating governance systems to institutionalize collaborative and integrated resource management}

The translation of multidisciplinary research results into participatory development actions requires providing stakeholders with organizational arrangements that allow them to coordinate and jointly decide on collective actions. Improved communication linkages and the endorsement of ecological concerns across decision levels are important requirements so that the resulting governance system can promote policies based on collaborative and integrated resource management. Collaborative land-use planning, a concept that is still very weakly implemented in developing countries, has potential to integrate sectors and perspectives and to set the stage for more sustainable initiatives, as shown in our case studies. Research must also focus on the means to influence policy processes more than policy makers with regard to sustainability.

\section{Designing and supporting enabler organizations close to local communities}

The facilitation of the collective design of development actions among stakeholders does not guarantee that the consideration of the ecological dimension results in concrete actions. Even when multidisciplinary approaches for participatory development create positive dynamics, the translation from research to development-scale actions remains problematic, and the numerous publications on the subject have apparently had no impact thus far. Regular interactions among stakeholders are needed at the village level to understand local issues and trends, as well as to provide information. Whereas decentralization processes often bring political decisions closer to local populations, they have not been linked to corresponding extension or support services for improved resource management and local governance. A new way to sustain changes and reinforce participative agreements is needed. The creation of support services to bridge the gaps between actual resource management, decisionmaking processes, and market forces is a topic that should be the new focus of more advanced research on accounting for the ecological dimension.

Responses to this article can be read online at: http://www.ecologyandsociety.org/vol13/iss 1/art15/responses/

\section{Acknowledgments:}

This paper is based on an oral presentation that was given at the ECOSUMMIT 2007 congress "Ecological Complexity and Sustainability," Beijing, May 25-27. The research was partially funded by the European Commission; the Center International for Research on Agronomy and Development (CIRAD); BirdLife Indonesia (Tanimbar); the Swiss Agency for Development and Cooperation (Madagascar); and the UNDP, UNESCO, and UNV (Mahakam). We acknowledge these institutions and P. Levang, who offered comments on an earlier draft of this paper. Three anonymous reviewers for this journal provided useful critiques and insights, for which they are appreciated. 


\section{LITERATURE CITED}

Andrianandrasana, H. T., J. Randriamahefasoa, J. Durbin, R. E. Lewis, and J. H. Ratsimbazafy. 2005. Participatory ecological monitoring of the Alaotra wetlands in Madagascar. Biodiversity and Conservation 14(11):2757-2774.

Asian Development Bank. 1996. Mainstreaming participatory development processes. Office of Environment and Social Development, Asian Development Bank, Manila, The Philippines. [online] URL: http://www.adb.org/Documents/Gui delines/Mainstreaming-Participatory-Dev/default.asp

Astawa, I. M. B., A. Tao, B. Shantiko, S. Huninhatu, D. Amarduan, and J. Pareira. 2006. Building a common vision on Yamdena Island development. European Union-Tanimbar Land Use Planning Project Technical Series, Number 10. Office of the European Commission Delegation in Jakarta, Indonesia.

Berkes, F., and C. Folke, editors. 1998. Linking social and ecological systems: management practices and social mechanisms for building resilience. Cambridge University Press, Cambridge, UK.

Berkes, F., M. Kislalioglu, C. Folke, and M. Gadgil. 1998. Exploring the basic ecological unit: ecosystem-like concepts in traditional societies. Ecosystems 1(5):409-415.

Bertrand, A. 1999. La gestion contractuelle, pluraliste et subsidiaire des ressources renouvelables à Madagascar (1994-1998). In R. R. Marcus and C. Kull, editors. The politics of conservation in Madagascar. African Studies Quarterly 3(2). [online] URL: http://web.africa.ufl.edu/asq/v3/v3i2a6. htm.

Bourgeois, R., A. Gouyon, F. Jésus, P. Levang, W. Langeraar, F. Rahmadani, E. Sudiono, and B. Sulistiani. 2002. A socioeconomic and institutional analysis of Mahakam Delta stakeholders. Unpublished report to Total Fina Elf, Jakarta, Indonesia.

Bourgeois, R., and D. Herrera. 2003. Actor-led change for efficient agrifood systems. Handbook of the participatory actor-based CADIAC (commoditychain analysis and action-oriented dialogue) approach. CGPRT Publication Number 39.
CGPRT/CIRAD, Bogor, Indonesia.

Bourgeois, R., and F. Jésus, editors. 2004. Participatory prospective analysis: exploring and anticipating challenges with stakeholders. CAPSA Monograph Number 46. UNESCAP-CAPSA, Bogor, Indonesia. Available online at: http://www. uncapsa.org/Monograph Detail.asp?VListNo $=4 \&$ VPage $=1$

Bourgeois, R., F. Rahmadani, and T. Hidayat. 2004. Sustainable management of the Mahakam Delta resources, programme proposal. United Nations Development Programme, Jakarta, Indonesia.

Brand, J. 1998. The agro-ecological system on the eastern escarpment of Madagascar: resource-and use-dynamics under slash-and-burn. Dissertation. University of Bern, Bern, Switzerland.

Brand, J., and J.-L. Pfund. 1998. Site- and watershed-level assessment of nutrient dynamics under shifting cultivation in eastern Madagascar. Agriculture, Ecosystems and Environment $\mathbf{7 1}$ (1-3):169-183.

Brinkerhoff, D. W. 1997. Integrating institutional and implementation issues into policy decisions: an introduction and overview. Pages 1-18 in D. W. Brinkerhoff, editor. Policy analysis concepts and methods: an institutional and implementation focus. JAI Press, London, UK.

Brinkerhoff, D. W., and J.-C. Garcia-Zamor, editors. 1986. Politics, projects, and people: institutional development in Haiti. Praeger, New York, New York, USA.

Campbell, L. M., and A. Vainio-Mattila. 2003. Participatory development and community-based conservation: opportunities missed for lessons learned? Human Ecology 31(3):417-437.

Cernea, M. M., editor. 1991. Putting people first: sociological variables in rural development. Oxford University Press, New York, New York, USA.

Colchester, M. 2006. Justice in the forest: rural livelihoods and forest law enforcement. CIFOR, Bogor, Indonesia.

Colfer, C. J. P. 2005. The complex forest: communities, uncertainty, and adaptive collaborative management. Resources for the Future, Washington, D.C., and CIFOR, Bogor, Indonesia. 
Creocean. 2000. Mahakam Delta 1999 environmental baseline survey. Unpublished report to Total Indonésie, Jakarta, Indonesia.

Cunliffe, R. N., T. J. P. Lynam, D. Sheil, M. Wan, A. Salim, I. Basuki, and H. Priyadi. 2007. Developing a predictive understanding of landscape importance to the Punan-Pelancau of East Kalimantan, Borneo. Ambio 36(7):593-599.

Dalal-Clayton, B., and B. Sadler. 2005. Strategic environmental assessment: a source book and reference guide to international experience. Earthscan, London, UK.

Dale, V. H., and R. A. Haeuber, editors. 2001. Applying ecological principles to land management. Springer, New York, New York, USA.

Faramalala, M. H. 1995. Formations végétales et domaine forestier national de Madagascar. Scale 1:1,000,000 [color map]. Conservation International, Washington, D.C., USA.

Folke C., S. Carpenter, T. Elmqvist, L. Gunderson, C. S. Holling, and B. Walker. 2002. Resilience and sustainable development: building adaptive capacity in a world of transformations. Ambio 31(5):437-440.

Folke, C., L. Pritchard, Jr., F. Berkes, J. Colding, and U. Svedin. 2007. The problem of fit between ecosystems and institutions: ten years later. Ecology and Society 12(1): 30. [online] URL: http://www.e cologyandsociety.org/vol12/iss1/art30/.

Forman, R. T. T. 1995. Land mosaics: the ecology of landscapes and regions. Cambridge University Press, Cambridge, UK.

Forman, R. T. T., and M. Godron. 1986. Landscape ecology. Wiley, New York, New York, USA.

Frost, P., B. Campbell, G. Medina, and L. Usongo. 2006. Landscape-scale approaches for integrated natural resource management in tropical forest landscapes. Ecology and Society 11(2): 30. [online] URL: http://www.ecologyandsociety.org/vol11/ iss2/art30/.

Gonsalves, J., T. Becker, A. Braun, D. Campilan, H. de Chavez, E. Fajber, M. Kapiriri, J. Rivaca-
Caminade, and R. Vernooy, editors. 2005. Participatory research and development for sustainable agriculture and natural resource management: a sourcebook. Three volumes. CIPUPWARD/International Development Research Centre, Ottawa, Canada. [online] URL: http://www. idrc.ca/en/ev-73443-201-1-DO TOPIC.html.

Green, G. M., and R.W. Sussman. 1990. Deforestation history of the eastern rain forests of Madagascar from satellite images. Science 248:212-215.

Hannah, L., B. Rakotosamimanana, J. Ganzhorn, R. A. Mittermeier, S. Olivieri, L. Iyer, S. Rajaobelina, J. Hough, F. Andriamialisoa, I. Bowles, and G. Tilkin. 1998. Participatory planning, scientific priorities, and landscape conservation in Madagascar. Environmental Conservation 25(1):30-36.

Hein, L. 2002. Toward improved environmental and social management of Indian shrimp farming. Environmental Management 29(3):349-359.

Hooker, M. B. 1978. Adat law in modern Indonesia. Oxford University Press, Kuala Lumpur, Malaysia.

Hopley, D. 1999. Assessment of the environmental status and prospects of aquaculture in the Mahakam Delta, East Kalimantan, Indonesia. Unpublished report to Total Indonesia, Jakarta, Indonesia.

Horning, N. R. 2005. The cost of ignoring rules: forest conservation and rural livelihood outcomes in Madagascar. Forests, Trees and Livelihoods 15:149-166.

Huitric, M., C. Folke, and N. Kautsky. 2002. Development and government policies of the shrimp farming industry in Thailand in relation to mangrove ecosystems. Ecological Economics $\mathbf{4 0}$ (3):441-455.

Hume, D. W. 2006. Swidden agriculture and conservation in eastern Madagascar: stakeholder perspectives and cultural belief systems. Conservation and Society 4(2):287-303.

Hurni, H., and J. Ramamonjisoa, editors. 1999. African mountain development in a changing world. African Mountains Association, Antananarivo, Madagascar, and Geographica Bernensia, Bern, Switzerland. 
Jensen, M. E., and P. S. Bourgeron, editors. 2001. A guidebook for integrated ecological assessments. Springer, New York, New York, USA.

Jésus, F., and R. Bourgeois. 2002. PACT, a tool for a practical alternative to the co-ordination of actors through market mechanisms. Paper presented at the Seventh Biennial Conference of the International Society for Ecological Economics. Sousse, Tunisia.

Jésus, F., and R. Bourgeois, editors. 2003. Reconciling actors' preferences in agricultural policy: towards a new management of public decisions. CGPRT Publication Number 44, CGPRT/CIRAD, Bogor, Indonesia.

Jewell, N., Y. Laumonier, R. Nasi, J.-M. Roda, and A. Billand. 2006. Land use planning, forestry and ecotourism in the Tanimbar Islands. European Union-Tanimbar Land Use Planning Project Technical Series, Number 9. Office of the European Commission Delegation in Jakarta, Indonesia.

Kautsky, N., P. Rönnbäck, M. Tedengren, and M. Troell. 2000. Ecosystem perspectives on management of disease in shrimp pond farming. Aquaculture 191(1-3):145-161.

Laumonier, Y. 2006. Tanimbar land use planning project. Final recommendations. Unpublished report. CIRAD, Jakarta, Indonesia.

Levang, P. 2002. Mangroves, shrimps and punggawa. An historical analysis of the development of the Mahakam Delta (East Kalimantan). Unpublished report to PT Win and Total Fina Elf, Jakarta, Indonesia.

Lidon, B., and B. Kartiwa. 2005. Appraisal of agroclimatological and hydrological conditions of Tanimbar Islands: potential and constraints. European Union-Tanimbar Land Use Planning Project Technical Series, Number 6. Office of the European Commission Delegation in Jakarta, Indonesia.

Macintosh, D. J., and S. Zisman. 1997. The status of mangrove ecosystems: trends in the utilization and management of mangrove resources. Unpublished report. International Union of Forest Research Organizations, Vienna, Austria. Available online at: http://www.iufro.org/download/file/2480 195/10700-mangrove-ecosystems.doc.
Maldidier, C. 2001. La décentralisation de la gestion des ressources renouvelables à Madagascar: les premiers enseignements sur les processus en cours et les méthodes d'intervention. Gelose Project. [online] URL: http://www.foncier-develop pement.org/analyses-et-debats/operations-foncieres/ la-decentralisation-de-la-gestion-des-ressourcesrenouvelables-a-madagascar-les-premiers-enseignements/

Marsden, D., and P. Oakley, editors. 1990. Evaluating social development projects. Oxfam, Oxford, UK.

Mertz, O., R. L. Wadley, U. Nielsen, T. B. Bruun, C. J. P. Colfer, A. de Neergaard, M. R. Jepsen, T. Martinussen, Q. Zhao, G. T. Noweg, and J. Magid. 2008. A fresh look at shifting cultivation: fallow length an uncertain indicator of productivity. Agricultural Systems 96(1-3):75-84.

Messerli, P. 2006. Exploring innovative strategies for livelihoods in a slash-and-burn context in Madagascar. Experiencing the role of human geography on sustainability-oriented research. Geographica Helvetica 61(4):266-274.

Messerli, P., and J.-L. Pfund. 1999. Improvements of slash-and burn cultivation systems: an experience of systemic analysis in the Beforona region, Madagascar. Pages 83-101 in H. Hurni and J. Ramamonjisoa, editors. African mountain development in a changing world. African Mountains Association, Antananarivo, Madagascar, and Geographica Bernensia, Bern, Switzerland.

Montagne, P., Z. Razanamaharo, and A. Cooke, editors. 2007. Tanteza, le transfert de gestion à Madagascar: dix ans d'efforts. CIRAD, Montpellier, France, and Centre for Technical and Economic Information, Antananarivo, Madagascar.

Novaczek, I., I. H. T. Harkes, J. Sopacua, and M. D. D. Tatuhey. 2001. An institutional analysis of sasi laut in Maluku, Indonesia. International Center for Living Aquatic Resources Management (The World Fish Center) Technical Report 59. Penang, Malaysia.

Olsson, P., C. Folke, and F. Berkes. 2004. Adaptive comanagement for building resilience in socialecological systems. Environmental Management 34 (1):75-90. 
Persulessy, Y., E. Rizali, and F. Rangkoly. 2004. Biodiversity in Tanimbar Archipelago. European Union-Tanimbar Land Use Planning Project Technical Series, Number 2. Office of the European Commission Delegation in Jakarta, Indonesia.

Pfund, J.-L. 2000. Culture sur brûlis et gestion des ressources naturelles. Evolution et perspectives de trois terroirs ruraux du versant Est de Madagascar. Thesis. Swiss Federal Institute of Technology (ETH), Zurich, and École Polytechnique Fédérale de Lausanne, Lausanne, Switzerland.

Primavera, J. H. 2000. Development and conservation of Philippine mangroves: institutional issues. Ecological Economics 35(1):91-106.

Purwanto, Y., Y. Laumonier, and M. Malaka. 2004. Anthropology and ethnobiology of the people of Yamdena in Tanimbar Archipelago. European Union-Tanimbar Land Use Planning Project Technical Series, Number 4. Office of the European Commission Delegation in Jakarta, Indonesia.

Rees, W. E., and M. Wackernagel. 1994. Ecological footprints and appropriated carrying capacity: measuring the natural capital requirements of the human economy. Pages 362-390 in A.-M. Jansson, M. Hammer, C. Folke, and R. Costanza, editors. Investing in natural capital: the ecological economics approach to sustainability. Island Press, Washington, D.C., USA.

Sayer, J., and B. Campbell. 2004. The science of sustainable development: local livelihoods and the global environment. Cambridge University Press, Cambridge, UK.

Shantiko, B., Y. Andries, B. Morialkosu, and D. Amarduan. 2004. Socioeconomic analysis of rural Tanimbar. European Union-Tanimbar Land Use Planning Project Technical Series, Number 3. Office of the European Commission Delegation in Jakarta, Indonesia.

Sheil, D., R. Puri, M. Wan, I. Basuki, M. van Heist, N. Liswanti, S. Rukmiyati, I. Rachmatika, and I. Samsoedin. 2006. Recognizing local people's priorities for tropical forest biodiversity. Ambio 35(1):17-24.

Spaninks, F., and P. van Beukening. 1997. Economic evaluation of mangrove ecosystems: potential and limitations. CREED Working Paper
Series Number 14. [online] URL: http://www.iied.o rg/pubs/pdfs/8133IIED.pdf.

Stevens, C. J., I. Fraser, J. Mitchley, and M. B. Thomas. 2007. Making ecological science policyrelevant: issues of scale and disciplinary integration. Landscape Ecology 22(6):799-809.

Styger, E., H. M. Rakotondramasy, M. J. Pfeffer, E. C. M. Fernandes, and D. M. Bates. 2007. Influence of slash-and-burn farming practices on fallow succession and land degradation in the rainforest region of Madagascar. Agriculture, Ecosystems and Environment 119(3-4):257-269.

van Noordwijk, M., T. P. Tomich, and B. Verbist. 2001. Negotiation support models for integrated natural resource management in tropical forest margins. Conservation Ecology 5(2): 21. [online] URL: http://www.consecol.org/vol5/iss2/art21.

Vayda, A. P., and A. Sahur. 1985. Forest clearing and pepper farming by Bugis migrants in East Kalimantan: antecedents and impact. Indonesia 39:93-110.

Vermeulen, S., and D. Sheil. 2007. Partnerships for tropical conservation. Oryx 41(4):434-440.

World Bank. 1996. The World Bank participation sourcebook. World Bank, Washington, D.C., USA. Available online at: http://www.worldbank.org/wbi/ sourcebook/sbhome.htm.

Zerner, C. 1994. Transforming customary law and coastal management practices in the Maluku Islands, Indonesia, 1870-1992. Pages 80-112 in D. Western and R. Wright, editors. Natural connections: perspectives in community-based conservation. Island Press, Washington, D.C., USA.

Zuidema, P. A., and J. A. Sayer. 2003. Tropical forests in multi-functional landscapes: the need for new approaches to conservation and research. Pages 9-19 in P. A. Zuidema, editor. Tropical forests in multi-functional landscapes. Prince Bernhard Centre for International Nature Conservation, Utrecht University, Utrecht, The Netherlands.

Zurbuchen, J. 2004. Population development and land use dynamic on the eastern escarpment of Madagascar. Thesis. University of Bern, Bern, Switzerland. 